\section{References}

Appleby, A., Batson, G.A., Lassman, L.P. \& Simpson, C.A. (1964) Spinal cord compression by extramedullary haematopoiesis in myelosclerosis. J. Neurol. Neurosurg. Psychiat. 27, 313.

Ask-UPMARK, E. (1945) Tumour-simulating intra-thoracic heterotopia of bone marrow, Acta radiol. (Stockh.), 26, 425.

Brannan, D. (1927) Extramedullary hematopoiesis in anaemias. Bull. Johns Hopk. Hosp. 41104.

Close, A.S., Taira, Y. \& Cleveland, D.A. (1958) Spinal cord compression due to extramedullary hematopoiesis. Ann. intern. Med. 48, 421.

Craven, J.D. (1964) Renal glomerular osteodystrophy. Clin. Radiol. 15, 210.

Dent, C.E. (1955) Clinical section. Proc. roy. Soc. Med. 48, 530.

Dodge, O.G. \& Evans, D. (1956) Haemopoiesis in a presacral tumor (myelolipoma). J. Path. Bact. 72, 313.

Follis, R.H. \& JACKson, D.A. (1943) Renal osteomalacia and osteitis fibrosa in adults. Bull. Johns Hopk. Hosp. 72, 232.

Hanford, R.B., Schneider, G.F. \& MacCarthy, J.D. (1960) Massive thoracic extramedullary hemopoiesis. New Engl. J. Med. 263, 120.

KNOBLICH, R. (1960) Extramedullary hematopoiesis presenting as intrathoracic tumours. Report of a case in a patient with thalassemia minor. Cancer, 13, 462.
Korst, D.R., Clatanoff, D.V. \& Schilling, R.F. (1956) On myelofibrosis. Arch. intern. Med. 97, 169.

Leiberman, P.H., Rosvoll, R.V. \& Ley, A.B. (1965) Extramedullary myeloid tumors in primary myelofibrosis. Cancer, 18, 727.

Leigh, T.F., Corley, C.C., Jr, Huguley, C.M. \& Rogers, J.V., Jr (1959) Myelofibrosis. The general and radiologic findings in 25 proved cases. Amer. J. Roentgenol. 82, 183.

Lowman, R.M., Bloor, C.M. \& Newcomb, A.W. (1963) Thoracic extramedullary hematopoiesis. Dis. Chest. 44, 154.

Malamos, B., Papavasiliou, C. \& Avramis, A. (1962) Tumor-simulating intrathoracic extramedullary hemopoiesis. Report of a case. Acta radiol. (Stockh.), 57, 227.

Pitcock, J.A., Reinhard, E.H., Justus, B.W. \& MendelSOHN, R.S. (1962) A clinical and pathological study of 70 cases of myelofibrosis. Ann. intern. Med. 57, 73.

SeIdleR, R.C. \& BeCKer, J.A. (1964) Intrathoracic extramedullary hematopoiesis. Radiology, 83, 1057.

Shanks, S.C. \& Kerley, P. (1962) A Text-book of X-ray Diagnosis by British Authors, vol. 2, 3rd edn, p. 895. Lewis, London.

WyatT, J.P. \& Sommers, S.C. (1950) Chronic marrow failure, myelosclerosis and extramedullary hematopoiesis. Blood, 5, 329.

\title{
Neurofibromatosis with pancreatic duct obstruction and steatorrhoea
}

\author{
K. G. WORMSLEY \\ M.D., M.R.C.P. \\ V. F. SORRELL \\ M.B.(N.Z.), F.R.C.S.
}

\author{
W. F. W. E. LOGAN \\ M.B., M.R.C.P. \\ G. C. Cole \\ M.B., Ch.B.
}

Manchester Royal Infirmary

INVOLVEMENT of the alimentary tract is a well recognized and documented manifestation of neurofibromatosis, but there appears to be no record of steatorrhoea complicating this disorder. We have encountered two patients in whom steatorrhoea was due to obstruction of the pancreatic duct by neoplastic processes attributable to this disease.

\section{Case 1}

F.S., male, aged 40, was admitted to hospital for investigation of severe diarrhoea of 1 years duration associated with considerable weight loss. The faeces were typically fatty.

Examination revealed a cachectic anaemic man with oedema of the feet and the typical cutaneous stigmata of neurofibromatosis.
Investigation confirmed the presence of severe steatorrhoea (Table 1). Jejunal biopsy was normal but duodenal intubation with pancreatic stimulation (Burton et al., 1960) showed no appreciable pancreatic secretion although the biliary fraction was normal. Radiological studies of the alimentary tract and gall bladder were normal. The anaemia (Hb $9.6 \mathrm{~g} / 100 \mathrm{ml}$ ) was due to thalassemia minor ( $\beta$ chain type, $\mathrm{Hb} \mathrm{A}_{2} 4 \cdot 1 \%$, $\mathrm{Hb} \mathrm{F} 1 \cdot 5 \%$ ).

Laparotomy revealed a nodule $(7 \mathrm{~mm}$ diameter) on the medial wall of the second part of the duodenum at the orifice of the pancreatic duct, which was obstructed $1 \mathrm{~cm}$ from its entry into the duodenum. The pancreas was small and atrophic.

The bile duct opened into the duodenum $2 \mathrm{~cm}$ proximally to the pancreatic duct. The obstructing nodule was excised. Histological examination 
TABLE 1

Laboratory investigations of Cases 1 and 2*

\begin{tabular}{|c|c|c|c|c|c|c|}
\hline & \multirow[b]{2}{*}{ Normal values } & \multicolumn{2}{|c|}{ Case 1} & \multicolumn{3}{|c|}{ Case 2} \\
\hline & & Pre-operative & Post-operative & 1962 & 1963 & 1965 \\
\hline Haemoglobin ( $\mathrm{g} / 100 \mathrm{ml}$ blood $)$ & $11 \cdot 5-16 \cdot 5$ & $9 \cdot 0$ & $9 \cdot 6$ & 14 & $13 \cdot 5$ & $13 \cdot 5$ \\
\hline Vitamin $B_{12}(\mathrm{pg} / \mathrm{ml})$ & 120 & 227 & & 410 & & \\
\hline Folate $(\mathrm{g} / \mathrm{ml}$ serum $)$ & $3-8$ & $7 \cdot 3$ & & $1 \cdot 5$ & & \\
\hline Albumin $(\mathrm{g} / 100 \mathrm{ml}$ serum $)$ & $3 \cdot 5$ & $2 \cdot 3$ & $3 \cdot 7$ & $4 \cdot 5$ & & 4.3 \\
\hline Globulin $(\mathrm{g} / 100 \mathrm{ml}$ serum $)$ & $3 \cdot 5$ & $2 \cdot 1$ & $3 \cdot 0$ & $2 \cdot 4$ & & $2 \cdot 7$ \\
\hline Alkaline phosphatase (King Armstrong units) & 15 & 9 & 16 & $2 \overline{1}$ & 18 & 13 \\
\hline Amylase (Units $/ 100 \mathrm{ml}$ serum) & 120 & 30 & & 135 & & \\
\hline Lipase (Units $/ 100 \mathrm{ml}$ serum) & $1 \cdot 5$ & 1.9 & & 0.7 & & \\
\hline Calcium $(\mathrm{mg} / 100 \mathrm{ml}$ serum) & $9-11$ & $9 \cdot 4$ & $9 \cdot 5$ & $10 \cdot 3$ & $10 \cdot 2$ & $10 \cdot 3$ \\
\hline Phosphate $(\mathrm{mg} / 100 \mathrm{ml}$ serum) & $2-4$ & $2 \cdot 9$ & $3 \cdot 2$ & $1 \cdot 4$ & $2 \cdot 2$ & $3 \cdot 5$ \\
\hline Urinary calcium $(\mathrm{mg} / 24 \mathrm{hr})$ & 300 & 300 & & 150 & & \\
\hline Urinary phosphate $(\mathrm{mg} / 24 \mathrm{hr})$ & & & & 290 & & \\
\hline Faecal fat $(\mathrm{g} / 72 \mathrm{hr}) \dagger$ & 24 & 192 & 34 & $11 \cdot 2$ & & 31 \\
\hline
\end{tabular}

Case 1: Pre-operative xylose $(25 \mathrm{~g})$ and glucose tolerance tests normal.

Case 2: Augmented histamine test $-8.6 \mathrm{mEq} / 30 \mathrm{~min}$.

*Methods according to Varley (1962). $\quad \nmid 80 \mathrm{~g} /$ day intake.

showed that the nodule was a well-differentiated adenocarcinoma. The pancreatic acinar cells were completely replaced by fibrous tissue. The islet cells were well preserved. Chronic inflammatory cells were infiltrated around the pancreatic ducts.

Following operation, the patient gained weight rapidly, with hourly pancreatic extract supplementing a normal diet. Six months after the operation, the diarrhoea had ceased, and although steatorrhoea persisted, the faeces appeared normal macroscopically. The haematological findings were unchanged.

\section{Comment}

Neither neurofibromatosis nor thalassemia had been noted in other members of the patient's family and, owing to the dispersion and death, it proved impossible to investigate any relatives. Both conditions are uncommon, but thalassaemia is being discovered more frequently in persons of AngloSaxon stock (Callender \& Mallett, 1961 ; Beaven et al., 1964). The anaemia was at first thought to be related to the steatorrhoea (Dawson, Holdsworth \& Pitcher, 1964) but the raised $A_{2}$ and $F$ haemoglobins, typical of thalassaemia minor, were not changed by marked improvement in his nutritional status.

\section{Case 2}

E.K., female, aged 63. This patient first presented when 57 years old, with a 'stress' fracture of the right third metatarsal bone. One year later, she developed a similar fracture in the left foot. She was admitted to hospital in 1962 to investigate the cause of generalized bone pain.
Examination showed only typical marked cutaneous neurofibromatosis.

Investigations. The serum phosphorus levels were repeatedly low, and alkaline phosphatase levels slightly raised (Table 1). Radiologic survey of her skeleton showed multiple Looser's zones and bone biopsy confirmed the presence of osteomalacia with secondary osteitis fibrosa. Faecal fat estimations and urinary aminoacid chromatography were normal. She was given oral vitamin D $(50,000$ units daily) and the Looser's zones healed radiologically within 16 months. Six months before her death she developed overt steatorrhoea and paraplegia. She was re-admitted to hospital, where attempts at jejunal biopsy and duodenal intubation proved unsuccessful due to pyloric stenosis. Investigation of the neurological condition repeatedly revealed raised cerebro-spinal fluid protein $(80-90 \mathrm{mg} / 100$ $\mathrm{ml}$ ). Myelography showed no abnormality.

Operation to relieve pyloric stenosis before attempting metabolic studies revealed gross thickening of the pylorus, multiple neurofibromata of the small intestine and marked narrowing of the duodenal end of the pancreatic duct, with proximal dilatation and induration of the head of the pancreas. The tail of the pancreas was anastomosed into a Roux loop of the jejunum to permit retrograde pancreatic drainage. Biopsy of the jejunum showed normal appearances. Two days following the operation, the patient suddenly collapsed and died.

Necropsy failed to reveal a cause of death but confirmed the operative findings. A duodenal ulcer was found in the first part of the duodenum, reducing the lumen to a diameter of $4 \mathrm{~mm}$. The 
head and body of the pancreas were severely fibrosed with dilatation and thickening of the wall of the pancreatic duct. An ill-defined mass $(8 \mathrm{~mm}$ diameter) surrounded the termination of the pancreatic duct but did not involve the common bile duct. No accessory pancreatic duct was found. Microscopically, the lesion consisted of a neurofibroma containing a number of small pancreatic ducts, but without recognizable remains of the main pancreatic duct. The pancreas showed marked fibrosis with considerable residual acinar tissue and apparently normal islets. Sections of iliac crest showed much less severe osteomalacia (and no osteitis fibrosa) than in the bone biopsy taken 3 years previously. The parathyroid glands were normal. At the mid-dorsal level, the spinal cord contained a plaque of grey tissue $(5 \times 1.5 \mathrm{~cm})$ on the antero-lateral surface. A segment of the cord about $1 \mathrm{~cm}$ long immediately caudal to the mass showed gross atrophy. Sections of the cord lesion proved this mass to be a hamartomatous malformation.

\section{Comment}

The three main facets of this patient's illness were attributable to neurofibromatosis. Although osteomalacia has been noted previously in cases of this disease, both the steatorrhoea and neurological lesion were unique. However, unlike Case 1, the disorders of the alimentary system, although pathologically impressive, did not dominate the clinical picture.

\section{Discussion}

The association with neurofibromatosis of both adenocarcinoma obstructing the ampulla (Case Report 46312, 1960; Braun, 1958) and neurofibroma of the pancreas (Frileux et al., 1962) has been noted previously, but steatorrhoea is not recorded in these reports or in other studies of neurofibromatosis involving the upper alimentary tract (River, Silverstein \& Tope, 1956; Nilsson \& Jonsson, 1957 ; Wilson \& Anderson, 1960 ; Domart et al., 1960 ; Curran \& Forsythe, 1961; Collins, 1963). The cause of the steatorrhoea was clinically obvious in Case 1, who showed no pancreatic exocrine secretion. However, the nature of the pancreatic disease remained unclear until operation, since it is unusual for neoplasms of the head of the pancreas or ampulla to present with steatorrhoea without jaundice (Brunschwig, 1942; Brown et al., 1952 ; Pirart \& Desnuex, 1952; Smith, 1953 ; Gullick, 1959 ; Cattel, Warren \& Au, 1959; Hess, 1965). In both patients described here, steatorrhoea without jaundice was caused by obstruction of the pancreatic duct without obstruction of the biliary system, due to separate openings of the two ducts into the duodenum, an anatomical variant which has been found in up to $20 \%$ of subjects (Millbourn, 1950). The almost complete obstruction of pancreatic exocrine secretion in such cases appears to be due to lack of communication between the main and accessory pancreatic ductal systems.

The steatorrhoea in Case 2 did not become apparent clinically or biochemically until 6 months before her final admission to hospital. During the first admission, when she presented with osteomalacia, fat excretion was apparently normal. The osteomalacia associated with neurofibromatosis has been attributed to vitamin $D$ resistance (Dent, 1952 ; Nordin \& Fraser, 1953; Swann, 1954; Saville et al., 1955 ; Lievre, Block-Michel \& Camus, 1959) due to defective renal tubular phosphate reabsorption. Massive doses of vitamin $D$ have been required to cure the osteomalacia, except in Dent's cases in whom 50,000 units daily appeared to be sufficient. Our patient, whose unsatisfactory diet must have played some part in producing her bone disease, also showed radiological cure of her Looser's zones with 50,000 units of vitamin D daily. The effect of lower dosage was not studied. This patient also showed evidence of secondary hyperparathyroidism. However, unlike the patient of Clark, Lumberton \& Matthews (1953) our patient did not show any parathyroid abnormality at autopsy. It is not clear whether the osteomalacia of Case 2 is in any way related to her malabsorption. In previous reports of osteomalacia in neurofibromatosis, faecal fat had been normal where recorded (Dent, 1952; Nordin \& Fraser, 1953; Swann, 1954) except possibly in the patient of Koller \& Kuhn (1950) in whom an increased proportion of faecal fat was found. While osteomalacia has been described in several patients with overt chronic pancreatitis (Steinbach, Kolb \& Gilfillan, 1954 ; Badenoch, 1960 ; Seze et al., 1962 ; Lamotte-Barrillon et al., 1964 ; Hoffbrand, 1965) a situation most nearly resembling that of our patient is recorded by Lamotte-Barrillon et al. (1964) whose patient showed normal faecal fat on some occasions and slightly raised values on others. Perhaps the cause of the osteomalacia in the latter case (and perhaps in ours) was similar to that suggested by Moss, Waterhouse \& Terry (1965) in patients with gluten-sensitive enteropathy without steatorrhoea, namely, malabsorption of calcium. Furthermore, like the osteomalacia of neurofibromatosis, the osteomalacia associated with steatorrhoea may show resistance to therapy with vitamin D (Badenoch \& Fourman, 1954 ; Fourman, 1960) although no data specifically devoted to patients with pancreatic steatorrhoea appear to be available. The problems raised by the bone disease of 
Case 2 might have been resolved by the full metabolic studies planned for the post-operative period and we hope that publication of this report will lead to future analysis elsewhere when opportunity presents. Finally, it is of interest that this patient showed features of both the diseases associated with the name of Von Recklinghausen.

\section{Summary}

Two patients are reported with neurofibromatosis and steatorrhoea due to pancreatic duct obstruction, by an adenocarcinoma of the papilla in one case and by a neurofibroma of the head of the pancreas in the other.

The relationship of the steatorrhoea to other clinical aspects of the disease processes of these two patients is discussed.

\section{Acknowledgments}

We wish to thank Dr E. G. Wade and Dr H. T. Howat for permission to report their patients; to $\mathrm{Dr} J$. Ball for commenting on the bone biopsies and to Dr J. E. McIver for the haematologic studies on Case 1. Both operations were performed by $\mathrm{Mr} \mathrm{H}$. B. Torrance.

\section{References}

BADENOCH, J. (1960) Steatorrhoea in the adult. Brit. med. J. ii, 879.

BADENOCH, J. \& Fourman, P. (1954) Osteomalacia in steatorrhoea. Quart. J. Med. 23, 165.

Beaven, G.H., Stevens, B.L., Ellis, M.J., White, J.C., Bernstock, L., Masters, P. \& Stapleton, T. (1964) Studies on foetal haemoglobin. IV. Thalassaemia-like conditions in British families. Brit. J. Haemat. 10, 1.

Braun, W. (1958) Karzinom der Papilla Vateri dei Morbus Recklinghausen. Derm. Wschr. 137, 513.

Brown, R.K., Moseley, V., Pratt, T.T. \& Pratt, J.H. (1952). The early diagnosis of cancer of the pancreas based on the clinical and pathological study of one hundred autopsied cases. Amer. J. med. Sci. 223, 349.

BrunsChWIG, A. (1942) The Surgery of Pancreatic Tumors, p. 198. Kimpton, London.

Burton, P., Evans, D.G., Harper, A.A., Howat, H.T., Oleesky, S., Scott, J.E. \& VARLey, H. (1960) A test of pancreatic function in man based on the analysis of duodenal contents after administration of secretin and pancreazymin. Gut, 1, 111 .

Callender, S.T. \& Mallett, B.J. (1961) Thalassaemia in Britain. Brit. J. Haemat. 7, 1.

Case Report of the Massachusetts General Hospital (No. 46312). (1960) New Engl. J. Med. 263, 251.

Cattell, R.B., Warren, K.W. \& Au, F.T.C. (1959) Periampullary carcinoma. Surg. Clin. N. Amer. 39, 781.

Clarke, D.H., Lumberton, N.C. \& Matthews, W.R. (1953) Simultaneous occurence of von Recklinghausen's neurofibromatosis and osteitis fibrosa cystica. Surgery, 33, 434.

Collins, N.P. (1963) Intestinal hemorrhage in von Recklinghausen's disease. Arch. Surg. 87, 374.
Curran, R.L. \& Forsythe, T. (1961) An unusual cause of gastrointestinal hemorrhage : systemic neurofibromatosis with involvement of the duodenum. Rhode Isl. med. J. 44, 644.

Dawson, A.M., Holdsworth, C.D. \& Pitcher, C.S. (1964) Sideroblastic anaemia in adult coeliac disease. Gut, 5, 304.

DENT, C.E. (1952) Rickets and osteomalacia from renal tubule defects. J. Bone Jt Surg. 34B, 266.

Domart, A., Wolfromm, R., Tourneur, R., Hazard, J. \& Quintrec, Y. (1960) Localisations gastro-duodenales et pulmonaires au cours de l'evolution d'une neurofibromatose de Recklinghausen. Presse med. 68, 1746.

Fourman, P. (1960). Calcium Metabolism in Bone Disease, p. 141. Blackwell Scientific Publications, Oxford.

Frileux, J., Terquem, R., Wiel, R. \& Henry, J.G. (1962) Sur les schwannomes du pancreas. Arch. Mal. Appar. dig. 51, 721 .

Gullick, H.D. (1959) Carcinoma of the pancreas. A review and critical study of one hundred cases. Medicine (Baltimore), 38, 47.

Hess, W. (1965) Surgery of the Biliary Passages and the Pancreas, pp. 123 and 125. Van Nostrand, Princeton.

HoffBRAND, I. (1965) Chronic pancreatitis with osteomalacia (Case Report). Proc. roy. Soc. Med. 58, 697.

Koller, F. \& KUHN, H. (1950) Osteomalacia bei Neurofibromatosis. Schweiz. med. Wschr. 80, 1316.

Lamotte-Barrillon, S., Bernier, J.J., Tricoire, J. \& CABrousse, C. (1964) Grande osteomalacie et pancreatite calcifiante. Presse med. 72, 3441 .

Lievre, J.A., Block-Michel, H. \& Camus, J.P. (1959) La demineralisation diffuse du spuelette dans la neurofibromatose. Rev. Rhum. 26, 253.

MillbourN, E. (1950) On the excretory ducts of the pancreas in man, with special reference to their relations to each other, to the common bile duct and to the duodenum. Acta anat. (Basel), 9, 1.

Moss, A.J., Waterhouse, C. \& Terry, R. (1965) Gluten sensitive enteropathy with osteomalacia but without steatorrhoea. New Engl. J. Med. 272, 825.

NiLSSON, B. \& JoNsSON, I. (1957) Malignant neurinoma of the duodenum. Acta chir. scand. 113, 357.

Nordin, B.E.C. \& FraSER, R. (1953) Vitamin D resistant osteomalacia associated with neurofibromatosis. Proc. roy. Soc. Med. 46, 302.

Pirart, J. \& Desneux, J.J. (1952) Duex cas de cancer pancreatique simulant: l'un une pancreatite chronique, l'autre une sprue idiopathique. Acta gastro-ent. belg. 15, 99.

River, L., Silverstein, J. \& Tope, J.W. (1956) Benign neoplasms of the small intestine. Int. Abstr. Surg. 102, 1.

Saville, P.D., Nassim, J.R., Stevenson, F.H., Mulligan, L. \& CAREY, M. (1965) Osteomalacia in von Recklinghausen's neurofibromatosis. Brit. med. J. i, 1311.

Seze, S., Lichtwitz, A., Ryckewaert, A., Bordier, P., Hioco, H. \& Mazabraud, A. (1962) Le syndrome de Looser-Milkman : etude de 60 cas. Sem. Hôp. Paris, 38, 2005.

Sмiтh, R. (1953) The Surgery of Pancreatic Neoplasms, p. 26. Livingstone, Edinburgh.

Steinbach, H.L., Kolb, F.C. \& Gilfillan, R. (1954) A mechanism of the production of pseudo-fractures in osteomalacia. Radiology, 62, 388.

SwanN, G.F. (1954) Pathogenesis of bone lesions in neurofibromatosis. Brit. J. Radiol. 27, 623.

Varley, H. (1962) Practical Clinical Chemistry, 3rd edn. Heineman, London.

Wilson, J.S. \& Anderson, A.A. (1960) Cutaneous and intestinal neurofibromatosis. Amer. J. Surg. 100, 761. 